Article

\title{
The Limits of Liberalism and the Crisis of Democratic Cosmopolitanism
}

Paul Krause

\begin{abstract}
The twentieth century saw the rise of internationalism among various liberal nation-states. By the end of twentieth century, there was hope among liberal intellectuals that the end of the Cold War would usher in the "end of history." However, the twenty-first century has seen a resurgence of isolationist and relativist doctrines in the sphere of international politics that threatens to impede the influence of liberal doctrine, institutions, and most importantly, international law. This paper assesses the development of Western liberalism and the "idea of progress" through the following: conflict; liberalism's implied epiphenomenalism over and against historical circumstances that led to the rise of liberal democracies; how various Hegelians have utilized Hegel to understand the liberal vision; and why the expansion of liberalism as a global and universal political philosophy has slowed.
\end{abstract}

Keywords: Hegelianism, liberalism, political philosophy, democracy

$\mathrm{T}$ The contemporary crisis of political liberalism has become a recent focus of many studies and has been diagnosed to be a result of a crisis of selfconfidence, the abandonment of faith in the idea of progress, failure to achieve a more equitable political economy for all, or more apoplectically, as a wholesale rejection of the so-called "Enlightenment model" of politics which threatens liberal democracy itself. ${ }^{1}$ The current state of liberal despair contrasts acutely with the enthusiasm for liberalism that was seen at the end of the twentieth century, which saw the rise of internationalism among liberal nation-states through the promotion of a (hopeful) new international order where democracy, human rights, civil rights, and global economics would flourish. All of these led some to speculate about the possibility of the "end

${ }^{1}$ For recent studies, see Edward Luce, Retreat of Western Liberalism (New York: Atlantic Monthly Press, 2017); Mark Lilla, The Once and Future Liberal (New York: HarperCollins, 2017); Douglas Murray, The Strange Death of Europe (New York: Bloomsbury Press, 2017); and Wendy Brown, Undoing the Demos (Cambridge: MIT Press, 2015) for such examples.

(C) 2017 Paul Krause

https://www.kritike.org/journal/issue 21/krause december2017.pdf

ISSN 1908-7330

$(c c)$ BY-NC-ND 
of history." ${ }^{2}$ However, the twenty-first century has seen a resurgence of isolationist and relativist doctrines in the spheres of both domestic and international politics that supposedly threaten to impede (if not cause the collapse of) the progress of liberal gains over the past half-century.

One of the greatest issues that the international community will struggle with is one which the world has been struggling with since the end of the Cold War, namely, the tension between liberal expansion and retrenchment (or retreat) on the global stage. By liberal expansionism, I am referring to the idea that liberal democratic states should work together, economically, politically, and even militarily (though often minimally advocated) to advance liberal goals and establish a global order that all nation-states (irrespective of geographic location, culture, religious identity, and internal politics) should be bound to some form of adherence to international law and treaties, market-oriented economics, and human rights moreover than purely domestic political constitutions and concerns which, in many instances, run counter to these aforementioned ideals. The current crisis of global liberalism can seemingly be attributed to the rise of "homogeneous mass democracy" which promotes a collective identity wrapped in the language of liberalism and equality, but denies any such rights to the foreign non-national. ${ }^{3}$ This crisis is highlighted in the moral dilemma that arises when liberal societies adopt realist principles in the pursuit of national or internationalist ends, ${ }^{4}$ which has been exacerbated in our growing globalized and pluralized world.

The problem of pursuing any long-standing international political theory is that it is ultimately tied to the domestic body politic-or as Max

2 I take this quote from Francis Fukuyama's thesis and elaboration on a liberalized Hegelian reading in his essay "The End of History?" in The National Interest 16 (Summer 1989), 3-18. See his expanded version, The End of History and the Last Man (New York: Free Press, 1992). Fukuyama, while revising aspects of his original thesis, still maintains that liberal democracy is still the unchallenged primary model for socio-political development and governance. For this, see Francis Fukuyama, Political Order and Political Decay (New York: Farrar, Straus and Giroux, 2014).

3 Carl Schmitt, The Crisis of Parliamentary Democracy, trans. by Ellen Kennedy (Cambridge: MIT Press, 1988), 1-17. Schmitt's "homogeneous mass democracy" can be surmised as being a highly nationalistic and exclusivist approach to democratic politics. This is highly nationalistic and exclusivist approach to democratic politics serves as the major hurdle for the internationalist democratic spirit to overcome. Schmitt himself seems to be aware of this tension in The Concept of the Political, where he later explains the antitheses of the politic are hindrances for the consummation of the political State.

${ }^{4}$ Paul Berman, Terror and Liberalism (New York: W.W. Norton \& Company, 2003), 8-9. Here, he argues that while "realist" foreign policy has some merit, it otherwise lacks a humanitarian and moral foundation. He asserts that a new internationalist foreign policy, while taking into consideration realist (economic, or, national security interests) concerns, needs to be re-invigorated with moral sensibilities and humanitarian concerns as well.

(c) 2017 Paul Krause

https://www.kritike.org/journal/issue 21/krause december2017.pdf

ISSN 1908-7330

(cc) BY-NC-ND 
Weber calls it, Sache. ${ }^{5}$ The Sache (cause) of the domestic body politic, furthermore, tends to be narrowly focused on immediate material concerns with the tendency toward an exclusivist outlook concerned with the "matter in hand" that poses problems for a political cause that is more universal in outlook. ${ }^{6}$ The domestic political cause seems to be closer in the spirit of Schmitt's "homogenous mass democracy" where concern for the friend - or "us" - takes primacy over the "other" and is at the heart of the concept of the political. ${ }^{7}$ And if politicians, in concordance with Sache, mean that they will act with a sense of responsibility to the cause, ${ }^{8}$ the immediate question arises: to which cause, then, does politics decide to passionately engage in? Moreover, what balance, if any, can be struck between the exclusive and universal?

These issues pose inherent problems to the very notion of liberal internationalism, which, through its implicit universal conception of itself, attempts to forge and maintain an internal order and promote an internal agenda that inevitably might find itself at odds with the domestic political body. After all, the very notion of the realist "national interest" outlookwhile not necessarily excluding internationalism and multilateralism by any means-takes a more serious and sobering account of what is ultimately in the interest of the domestic body politic over and against international concerns of humanitarianism, human rights, and global idealism. I will insist that the crisis of liberalism and the phenomenon of cosmopolitan democracy was the result of the embrace of an implicitly deterministic view of history that originally understood itself in a revisionist Hegelian manner of an actualized universal self-consciousness that embraced the concept of global community over and against national or tribal bonds. ${ }^{9}$ Presently, that vigorous embrace of a progressive reading of Hegel that propelled modern liberalism to the fore as the triumphant and universal ideology over its competitors is now in question. Is liberalism, construed as the ultimate

\footnotetext{
5 Max Weber, "Politics as a Vocation" in The Vocation Lectures, trans. by Rodney Livingstone (Indianapolis: Hackett Publishing, 2004), 76-77. In using The Vocation Lectures, which includes "Science as a Vocation" and "Politics as a Vocation," I have focused solely on Weber's "Politics as a Vocation."

${ }^{6}$ Ibid.

${ }^{7}$ Carl Schmitt, The Concept of the Political, trans. by George Schwab (Chicago: University of Chicago Press, 2007), 26-27.

${ }^{8}$ Weber, "Politics as a Vocation," 77.

${ }^{9}$ G.W.F. Hegel, Phenomenology of Spirit, trans. by A.V. Miller (New York: Oxford University Press, 1977), § 566-569. Hegel discusses, in these sections, how the "act of consciousness" sublates "faith" but that faith acknowledges contingent knowledge which permits concrete relationships with others (or "contingent things"). It is this outgrowth of consciousness from faith which, I argue, expands itself to the universal as appropriated in the growth of a political consciousness that moved to sublate old national communities and progress toward the embrace of the global community within modern liberalism.
}

(C) 2017 Paul Krause

https://www.kritike.org/journal/issue 21/krause december2017.pdf

ISSN 1908-7330

(cc) BY-NC-ND 
outcome of the march of history, just a philosophy that advances material gain via conatus and individual self-interest and survivalism, ${ }^{10}$ or does it have roots in culture, religion, and history from which these roots and circumstances help form the grounding for ethical action in the world? ${ }^{11}$

\section{The Roots of Liberalism and Its Evolution}

Historically, democracies have been highly nationalistic and have tended to be exclusive and homogeneous, rather than multicultural, cosmopolitan, and universalistic. ${ }^{12}$ The roots of these nationalistic and exclusivist origins of democracy and republicanism which later evolved into what we might call "liberalism" today can be traced back to religion. ${ }^{13}$ For example, three of the greatest powers that spurred the Western republican and democratic traditions - the Dutch Republic, England (United Kingdom), and United States - were all fervently Protestant nationalist strongholds that held deep anti-Catholic prejudices, often with exclusionary laws forbidding non-nationals the right to vote or equality under the law (until recently). $\cdot^{14}$ The very institution of the nation-state and of liberal political philosophy grew in the soil of nationalism and suspicion of others, particularly within the Protestant-Catholic sectarian division in Europe and North America in which "Protestant[s] summon[ed] to return to the Biblical text [and] with it incessant appeals to God's constitutional preferences as embodied in Scripture." 15 As Bertrand Russell also noted, liberalism, in some way, was the "product of England and Holland ... it was Protestant [in character]."16 This is not a claim defending a vague notion of "Protestant Exceptionalism," but a historical observation that many observers in philosophy and political theory have long noted: the original liberal nation-states, or the nation-states that are identified

${ }^{10}$ This is the basic thesis in the political tracts of the classical liberal fathers: Thomas Hobbes, John Locke, and Baruch Spinoza. See, in particular, John Locke, Second Treatise of Government, ed. by C.B. Macpherson (Indianapolis: Hackett Publishing Company, 1980), § 25-51.

${ }^{11}$ See G.W.F. Hegel, Outlines of the Philosophy of Right, trans. by T.M. Knox (New York: Oxford University Press, 2008), § 142-157. Hegel does not argue that "liberalism" finds its ethical justifications through its shared community, "bond[s] of duty," family, or other particularities, but that ethical action itself is rooted in such bonds and duties of particularity from which all is unified in the constitution of the state.

12 See Yoram Hazony, "Nationalism and the Future of Freedom," in Mosaic (6 September 2016), < https://mosaicmagazine.com/essay/2016/09/nationalism-and-the-future-ofwestern-freedom/>.

${ }^{13}$ See Eric Nelson, The Hebrew Republic (Cambridge: Harvard University Press, 2010),

$1-22$.

${ }^{14}$ Hazony, "Nationalism and the Future of Freedom."

${ }^{15}$ Nelson, The Hebrew Republic, 2.

${ }^{16}$ Bertrand Russell, A History of Western Philosophy (New York: Routledge, 2004), 545.

(C) 2017 Paul Krause

https://www.kritike.org/journal/issue 21/krause december2017.pdf

ISSN 1908-7330

(cc) BY-NC-ND 
as having been leaders in the ascendency of liberalism, tended to be rooted in the Protestant religion. ${ }^{17}$

Over time, these Protestant nations tended to "liberalize" themselves by embracing stronger republican and democratic qualities as a reflection of national identity and self-determination in contradistinction to their Catholic rivals. This helped foster a culture of anti-Catholicism, whereby Catholic immigrants were perceived as having an allegiance to the Papacy instead of the Protestant national body politic that promoted civil Protestantism and civic nationalism as a means to preserve the newly won freedom and liberty. ${ }^{18}$ The principle of anti-Catholicism was not anti-Catholicism per se, but the "othering" of foreigners not part of the original national construction, which can be long attested to throughout human history. As Yoram Hazony states, "What made this possible, however, was not a doctrine enumerating a list of 'universal rights.' Rather, 'the ancient customs and privileges' of the [Protestant] people themselves were said to be responsible for their country's special regard for intellectual and religious freedom." 19

What is often neglected in public commentary is the deliberate exclusivist (anti-Catholic) construction of Protestant notions of "liberty" to push out the ideas of universalism and sacral authority associated with Catholicism. ${ }^{20}$ Even the notion of the now idealized "separation of Church and State" was an anti-Catholic Protestant construction. ${ }^{21}$ National identity, itself exclusionary and ubiquitous in the formation of notions of modern liberty during what Eric Nelson has called "the Hebrew Revival" of the sixteenth and seventeenth centuries, ${ }^{22}$ is one of the historical roots of modern democracy which materialized itself as self-determination rather than the

${ }_{17}$ In the particular case of the United States, the works of Perry Miller, Sacvan Bercovitch, Talcott Parsons, Louis Hartz, and Francis Bremer have all noted on the importance of Puritanism, in some fashion, helping to ground and shape American ideas of nation, democracy, and liberalism.

${ }_{18}$ One of the most glaring examples of such prejudices is seen in Paul Blanshard, American Freedom and Catholic Power (Boston: Beacon Press, 1949), where he argued that Catholic loyalties (to the Holy See) were antithetical and incompatible with the values the formed the basis of American political life and the Constitution of the United States. See also Glenn A. Moots, "The Protestant Roots of American Civil Religion," in Humanitas 23:1-2 (2010), 78-106 for the influence of Reformed Protestantism and anti-Catholic tendencies in shaping American political culture and civil society. Note, Prof. Moots' article is not promoting anti-Catholicism like Blanshard's book, but is a historical treatise on the importance of anti-Catholicism in early American history that subsequently became embedded in American public (Protestant) culture. ${ }^{19}$ Yoram Hazony, "Nationalism and the Future of Freedom."

48.

${ }^{20}$ Christopher Ferrara, Liberty, The God that Failed (Tacoma: Angelico Press, 2012), 42-

${ }^{21}$ See Philip Hamburger, Separation of Church and State (Cambridge: Harvard University Press, 2002).

${ }^{22}$ Nelson, The Hebrew Republic, 4.

(c) 2017 Paul Krause

https://www.kritike.org/journal/issue 21/krause december2017.pdf

ISSN 1908-7330

(c) $)$ BY-NC-ND 
incomparable abstraction of demos from Greek philosophy, ${ }^{23}$ Notwithstanding that the Greeks themselves were exclusionary in their thought as well. Therefore, one of the roots of modern democracy is national self-determination as the exercise of freedom of (religious) conscience. This is especially in religious matters that led to the Treaty of Augsburg which enshrined the principle: Cuius regio, eius religio.

The Treaty of Augsburg ultimately led to an idea of "constitutional pluralism" 24 that separated differing conceptions of governance and religious fidelity, rather than promote a universal abstraction as is the case with modern liberalism's insistence on human rights and democratic federalism. In other words, there was a well-defined constitutional principle that established well-defined borders that were to be respected during the origo of liberalism that was the residue of sectarian violence and religious wars. After all, the birth and growth of liberal democracies (and republics) in the Western World generally came out of the fires of sectarian violence, religious wars, and civil wars during the seventeenth through nineteenth centuries rather than the more "humane" metanarrative of an embrace of skepticism, tolerance, and openness of the Enlightenment that is often told. ${ }^{25}$

The evolution of a liberal democratic politics through the fire of hardship and the death of old orders can also be contrasted with liberalism's metaphysical, and broader philosophical, foundations in Baruch Spinoza, Thomas Hobbes, and John Locke, in which "liberalism's" chief metaphysical claim is that all human action is driven by rational self-motivation-or conatus. "Reason is not opposed to conatus, but conatus itself. It is not opposed to power, but power itself." 26 Through self-survival as the primary means of progress, the classical liberal theorists implicitly laid the groundworks for the eventual transcendence of liberalism's historically Protestant character. It was not Protestantism, per se, that influenced liberalism-since Protestantism was just a contingent epiphenomenon of material self-interest and survival-but that Protestantism leant itself to the

${ }^{23} \mathrm{Hegel} \mathrm{himself} \mathrm{suggests} \mathrm{that} \mathrm{various} \mathrm{roots:} \mathrm{religion,} \mathrm{culture,} \mathrm{and} \mathrm{language,} \mathrm{along} \mathrm{with}$ personal will, lead to the union of the citizen with the emergent state in history. See G.W.F. Hegel, Reason in History, trans. by Robert Hartman (Upper Saddle River: Library of Liberal Arts, 1997), 49. In this sense, the Protestant nations that would become the core liberal nations by the late Enlightenment achieved that divine idea of the state on earth with their constitutions and political institutions embodying their essential Protestant character, harkening back to what Eric Nelson claimed was the incessant Protestant appeal to form political orders according to "God's constitutional preferences as embodied in Scripture." See Nelson, The Hebrew Republic, 2.

${ }^{24}$ Nelson, The Hebrew Republic, 3.

${ }^{25}$ This is undoubtedly the case with Britain, Holland, and the United States, whose liberal mentality and politics were forged from religious wars, wars of independence, and civil wars during the "Enlightenment Era."

${ }_{26}$ Modesto Gómez-Alonso, "Spinoza on Freedom, Individual Rights, and Public Power," in Praxis Filosófica Nueva serie 40 (enero-junio 2015, 23). 
advancing interests of self-survival in a harsh world. In the sectarianism of the seventeenth century Protestantism coincidentally happened to align with, and support, the emergence of liberal thought. Thus, despite liberalism's and Protestantism's intertwined heritage-something that is not lost in the memory of certain Protestant sects-modern liberalism has now moved beyond Protestantism and its own historical boundaries and roots for having regarding these factors as mere coincidence and contingent epiphenomena of the exertion of one's individual conatus. Or has it?

Recent political developments across the world in the past few decades - from the Tiananmen Square Riots, the collapse of the Communist Bloc, and to the rise of the Arab Spring - would be pointed to as evidence of the universality of liberalism that stems from a universal rationality that emanates from our conatus. Lurking in contemporary democratic movements is a danger, however. In each case we can ask, what form of democracy is being appealed to: a nationalistic collective identity appeal (perhaps best seen in the latter developments of the Arab Spring revolutions by highly exclusivist politics and ethno-religious appeals), or a more open and pluralistic appeal? This only magnifies the problem for any international politics and international polity. Furthermore, the twenty-first century idealization of democracy often discounts the historical account of democracy's slow evolution from its own exclusivist and nationalist origo, not to mention whether it is actually correct to see any cultural and religious connection to liberalism as mere epiphenomenon or something far deeper.

Max Weber asserted with a bleak attitude that politicians were unlikely to make such commitments because it would betray the "passion" of the domestic political apparatus and their constituents. ${ }^{27}$ Likewise, Carl Schmitt observed a contradiction between the concerns that an ethnic national might have toward anyone who is deemed an enemy. ${ }^{28}$ In both cases, culture, domestic politics, and history are important to the liberal political project, not mere self-survivalism and economic rationalism that reduces all other "influences" as mere epiphenomenon. For Schmitt, the meta-political is rooted in the friend-enemy distinction, rather than ethical universalism or rationalistic consumerism. ${ }^{29}$ This reality returns us to the need for strongwilled international institutions, which themselves are dependent upon the strong leadership of supporting states; this is itself problematic out of the liberal heritage which also venerates the idea of a limited government in certain circles.

This strong will, however, of the liberal State in maintaining and promoting a global universalism runs into the dilemma of the State's

${ }^{27}$ Weber, “Politics as a Vocation," 35, 75-77.

${ }^{28}$ Schmitt, The Concept of the Political, 28.

${ }^{29}$ Ibid., 23..

(C) 2017 Paul Krause

https://www.kritike.org/journal/issue 21/krause december2017.pdf

ISSN 1908-7330

(c) BY-NC-ND 
domestic obligations. ${ }^{30}$ In any democracy, the domestic citizenry confers the legitimacy of the State since no democracy can sustain itself without the public trust and will. Yet, for Schmitt, such political universalism has to do away with markers of plurality and distinction since such distinctions are the antithesis of the political. ${ }^{31}$ Only by achieving this erosion of plurality can the State act free of its domestic obligations, the concerns of its peoples, and overcome historical culture, religion, or economic heritage ${ }^{32}$ and achieve its consummation in history. "In this universal society, there would no longer be nations in the form of political entities, no class struggles, and no enemy groupings." ${ }^{33}$ Inherent to Schmitt, then, is the opposing view that liberal democracy is not just rooted in pure conatus and self-survivalism but has additionally embedded roots in culture, religion, heritage, and self-identity (all of which now serve as antitheses to the universalism of liberalism which liberalism must overcome in order to actualize itself in totality).

The deterministic and epiphenomenal conception of liberal politics, however, doesn't take into account the democratic counter balance of the citizen's vote. At any given election, the domestic body politic can reject the State's universalism and seek a restoration of the politics with strictly domestic foci. In democracy, there always exists the possibility of rejecting the supposed synthesis through political voting. ${ }^{34}$ This "reactionary" counter to the consummation of the political, which serves to prevent the superseding consummation of the political against its antitheses, counteracts what Ryszard Legutko claims as "the idolatry of liberal democracy." 35 The totalitarian impulse in liberalism is the idolatry of the conception of the liberal politics as it seeks to supersede (and destroy) all competing antitheses to itthe Bodenständigkeit of any peoples. The totalitarian impulse emerges in response to the reaction against the universalizing tendency of the concept of the political; the "reactionary" impulse for a return to a politics of the domestic becomes the hurdle by which the liberal politic must now overcome-to achieve the Aufhebung that Hegel speaks of in the process of historical advancement.

Here emerges an additional tension between the Aufenthalt (dwelling) of liberalism's rootedness against its contemporary historicized universalistic ambitions. As Heidegger explains, our dwelling-which takes

\footnotetext{
${ }^{30}$ Ibid., 30-32.

${ }^{31}$ Ibid. 23-24.

${ }^{32}$ Ibid.

33 Ibid., 54.

${ }^{34}$ Ibid., 28. Schmitt claims that there is always the hope of the antithesis (the enemy in the friend-enemy distinction) being "vanished from the world." Insofar that nations are built on the "friend-enemy" distinction, and that this is the very nature of the concept of the political in of itself, there is no progressing beyond this antithesis.

${ }^{35}$ Ryszard Legutko, The Demon in Democracy (New York: Encounter Books, 2016), 24.
}

(c) 2017 Paul Krause

https://www.kritike.org/journal/issue 21/krause december2017.pdf

ISSN 1908-7330 
some form from the primal roots of our being-in-the-world-leads to an independent dwelling with others, ${ }^{36}$ but one in which there is no attachment (or dwelling) with the "other." The in-dwelling consciousness of liberalism's exclusivist, nationalist, and broadly Protestant heritage, in which its liberty was won through conflict against the other for-itself, now comes into conflict with the expansionist ideal of universalizing liberty beyond its own borders. The friend-enemy distinction that was engrained in early liberalism's consciousness now struggles, as Schmitt foresaw, to perceive and interpret itself in the world in much the same manner that Heidegger notes, that any dwelling seeks a want to preserve itself and refrain from being manipulated and used (by something) when it encounters another form of dwelling. ${ }^{37}$ There seems to be a natural insistence on wanting to preserve one's own roots which give meaning to one's being-in-the-world; and ethical order is grounded in one's possessed roots and experiences. ${ }^{38}$

The isolationist wing of the domestic body politic that is opposed to universal and international commitments might invoke nationalistic exclusionary democratic tendencies in arguing why one should not promote a cross-cultural and internationalist policy by returning to an "us vs. other" mentality. This would be a full reactive return to the politics of the domestic rooted in its historical past. Such "isolationist" sentiments would naturally strike the Hegelian liberal as reactionary and anti-progressive. That the inherent worth of human dignity and potentiality of the human spirit is contained in all, regardless of race, sex, or religion would no longer a guiding principle in political action. The struggle for dignity and the recognition of dignity, principally through the consummation of liberty, as the slow march of progress over time, would seem to be at bay and run opposite of liberalism's progressive and progressing understanding of itself in the world. In this reading of liberalism's ascendency in history, the rise of liberal democracy follows a simple pattern through history: nationalistic and exclusionary at first, becoming pluralistic as persons of differing ethnoreligious backgrounds begin to compose a larger demographic of the population, then emerges multicultural, cosmopolitan, and internationalist as a result of the concern for others becoming a top priority because the democracy is now filled with people from all across the world. ${ }^{39}$ Here, I need

${ }^{36}$ Martin Heidegger, Being and Time, trans. by Joan Stambaugh (Albany: State University of New York Press, 2010), I.II.62.

${ }^{37}$ Ibid.

${ }^{38}$ Hegel, Outlines of the Philosophy of Right, § 153.

${ }^{39}$ For example, the United States was largely composed of English persons with a Reformed Protestant religious background by the signing of the Declaration of Independence and formation of the Constitutional Government in 1788. America was dominated by the White Anglo-Saxon Protestant from the eighteenth century until the early twentieth century. As America became more diverse with the arrival of Irish, South German, and Southern European

(c) 2017 Paul Krause

https://www.kritike.org/journal/issue 21/krause december2017.pdf

ISSN 1908-7330

(c) $)$ BY-NC-ND 
to address what I mean by multiculturalism. By multiculturalism I mean people of different cultures, religious backgrounds, and ideological worldviews coming together to build a united and covenant-bound society, which is never statically ascertainable but always a work in progress..$^{40}$ Accordingly, to support democratic movements that might be nationalistic in disposition is the first step toward the evolution of a cosmopolitan democracy. By cosmopolitan democracy, I am referring to a multidimensional democracy not in the sense that one community is able to splinter off in peace and privacy to continue building communal enclaves of their own culture or religion and perpetuate a process of Balkanization, but coming together with persons of differing ethnic, religious, and cultural backgrounds to build a truly unique, cosmopolitan, and multicultural society. This internal cosmopolitan democracy, and how it emerges, is analogous to what Jacques Derrida calls the "democracy to come." 41

I should assert, or at least point out, that the evolution of democracy that was achieved through internal conflict that eventually fostered in democratic societies the ideal of free speech, a tolerant civil society, and the politics of self-correction. ${ }^{42}$ The greatest achievements of social and political reform were necessarily achieved through broad and committed social movements that relied on dialogue, conversation, and political assembly to advance their messages and influence the wider public. In time, the synthesis

Catholics, America became more cosmopolitan and the Anglo-Protestant stronghold in American politics receded and the former "foreigner" gained substantial rights and power. The twentieth century saw the influx of Jews and persons of a non-Abrahamic religious background flock to America for new opportunities, and the United States abandoned its longstanding policy of isolationism in favor of a broad internationalist commitment to the spread of liberal political philosophy, human rights, and civil rights, thus following the cycle of nationalist democracy, to cosmopolitan democracy with increasing rights to the former "non-national," to a democracy with internationalist concern and a cosmopolitan composition. See also, John Rawls, The Law of Peoples (Cambridge: Harvard University Press, 2001), 179-180. Rawls asserts that a pluralistic society of differing ethnic, religious, and philosophical backgrounds holding to seemingly irreconcilable doctrines helps foster a more reasonable society which is the hallmark of a liberal democratic state.

${ }^{40} \mathrm{I}$ borrow this idea of multiculturalism as an ongoing work in progress from Charles Taylor, Professor Emeritus at McGill University.

${ }^{41}$ Jacques Derrida, Politics of Friendship, trans. by George Collins (New York: Verso Books, 2005), 104. Derrida maintains that the expansion of democracy is a work in progress - "in the name of a democracy to come" -in which all persons are equally free in the standing of the democratic society in which they find themselves. There remains an inherent tension within democracy between the struggle between sovereignty (liberty) and equality. Derrida's "democracy to come" is not eschatological, or future oriented, but is about the ability of democracy to internally overcome its conflicts and shortcomings.

42 The "politics of self-correction," as I have outlined, seems to be analogous to Derrida's "democracy to come."

(c) 2017 Paul Krause

https://www.kritike.org/journal/issue 21/krause december2017.pdf

ISSN 1908-7330

(cc) BY-NC-ND 
that emerged after the dialectic of conflict was one of a more liberal, ${ }^{43}$ peaceable, and multicultural society, with laws now reflective of the newly accepted political beliefs forged through conflict and hardship moreover than the embrace of a lofty ideal that emerged only after the fact.

The genius of democratic evolution, so to speak, was the eventual push towards egalitarianism, which Alexis de Tocqueville observed as early as the nineteenth century. ${ }^{44}$ However, this push toward greater egalitarianism has generally been only among national citizens in the domestic body politic with scattered global and universal concerns visible-even into the twentyfirst century. There remains, then, what Schmitt observed, a hesitancy and tension within liberalism to extend its hand outward politically, but always willing to globalize economically. Thus, it became necessary for liberalism to overcome this political barrier in the twentieth century. But it was this overcoming of domestic, or national, liberalism that has led to discontent from the domestic body politics as Weber anticipated and Schmitt said is part of the inherent tension within (liberal) democracies.

\section{Modern Liberalism and the Struggle for the End of History}

Max Weber, using the same language as Hegel with regards to personal cause(Sache), and aware of the ethical dilemma involved in politics (what to concern oneself with), called for politicians to embrace their vocation with a passion while simultaneously rejecting the inflexible partisan commitments associated with a one-sided ethic of conviction (Gesinnungsethik). Weber promoted an ethic of conviction that has not been tempered and alloyed with the political ethic of responsibility, or Verantwortungsethik. ${ }^{45}$ To convey this point to his German audience, Weber deftly plays on resonances in the word Sache, meaning "cause" or "issue." In politics, passion, as Weber observes, is indispensable. Yet, passion for the Sache properly expresses itself in the virtue of the Sachlichkeit, "impartiality" or in Weber's usage, "realism." 46 Weber, then, enlists Sachlichkeit as the core of his political ethic of responsibility that might stand in opposition to the domestic body politic and political constituency for something more than mere petty and exclusivist politics. In a certain sense, although a realist, Weber argues along similar Hegelian lines of finding the necessary cause in

${ }^{43}$ By dialectic I am merely referring to the struggle between opposing forces, more analogous to the view offered by Schmitt; though Hegel also seems to posit that the essence of the dialectic is one forged and advanced through conflict.

${ }^{44}$ Alexis de Tocqueville, Democracy in America (New York: Bantam Dell, 2000), 543-545, 616-617.

${ }^{45}$ Weber, "Politics as a Vocation," 82-83, 92-94.

${ }^{46}$ This impartial objectivity ties together with passion to attain realistic goals while not betraying the Sache one is devoted to. It mixes passion for a realistic, or attainable, end.

(c) 2017 Paul Krause

https://www.kritike.org/journal/issue 21/krause december2017.pdf

ISSN 1908-7330

(c) BY-NC-ND 
politics to transcend the domestic agenda that will almost inevitably be favored over any international cause, concern, or strategy. The promise of a progressive world seems to have been Sache, manifest through modern liberalism's attempt to consummate universal peace and peaceable consumerism through the rise of liberal internationalism.

A key element to the success of this international liberal end was the strong political commitment to internationalist causes built upon by a new solidarity premised on a conflictual dialectic, principally the friend-enemy antithesis laid out by Schmitt. In the Cold War, for instance, it was easy for broadly "liberal" nations to work together against a mutual enemy (in this case, Stalinism). Fear, which Locke also identifies as making us willing to quit the original condition ${ }^{47}$ of the expansion of illiberal communism also eased the progression away from national isolationist tendencies toward a united international front which tied nations together politically, economically, and intellectually, to confront the source of this anxiety (real or imagined). In this sense too, so-called classical liberalism already has a foundation (in Locke) for the movement away from the transient national commonwealth to an embrace of something more concrete and progressive which binds multiple commonwealths together as one.

To counter, however, the potential fallback to a politics only concerned with the domestic cause, a wholly new concept of the political was needed: mainly, the embrace that an idea is revolutionary and to achieve the unanimity of liberal democracy across the globe, one must embrace a new dialectical orthodoxy because the dialectic is itself, revolutionary (and conflictual). ${ }^{48}$ The new dialectic-which saw liberalism overcoming its political opposition in the world through history-in support of internationalism would help spur a commitment to the advancement of democracy regardless of how "primitive" or nationalistic it would initially be. The promotion of liberal internationalism by way of this new conflictual dialectic in history would provide a greater awareness and reality of our relationship with all persons through a new human consciousness which achieves the dialectical "conception of totality." 49 Through this dialectical process of conflictual overcoming, one achieves a totality of consciousness where one's duty is to participate in the unfolding of the "right side" of history and aiding others in the struggle for "freedom." This new consciousness - a conscionable morality opening our awareness to the pains, struggles, and desires of all persons in the world who strive and struggle for freedom-would therefore necessitate a moral duty of action and take into

\footnotetext{
${ }^{47}$ Locke, Second Treatise of Government, § 123.

${ }^{48}$ Georg Lukács, History and Class Consciousness: Studies in Marxist Dialects, trans. by Rodney Livingstone (Cambridge: MIT Press, 1972), 2.

${ }^{49}$ Ibid., 3-12, 14.
}

(c) 2017 Paul Krause

https://www.kritike.org/journal/issue 21/krause december2017.pdf

ISSN 1908-7330 


\section{LIBERALISM AND DEMOCRATIC COSMOPOLITANISM}

consideration the international welfare of others, rather than abjectly turn a blind eye to their plight, which shall bring forth a personal fulfilment of the moral duty required for the universal end. ${ }^{50}$

To this end, twentieth century liberalism underwent a metamorphosis from national democracy to a conscionable universalism - a progressive Weltanschauung (worldview) in which this universal consciousness for freedom transcended all markers of plurality, nation, history, culture, and religion which were understood as the engines that drove the conflicts of the twentieth century and bound peoples and nations together in a common international cause. This shift, of course, was forged primarily through the Second World War. The Second World War opened anew the possibility of grounding a new shared experience and sense of duty to others which could serve as the grounds for new (universal) action in the world. ${ }^{51}$ At the same time, however, such a radical reappraisal of rights and duties could come into conflict with domestic concerns, issues, and particularity, which would have to be overcome in order to consummate this new worldview of the progressive unfolding of liberalism writ large.

The emphasis on general dialogue through the advocacy of a dialectic promoting democratic universalism would have to achieve the realization and self-knowledge that moral action supportive of the global whole is in the right: from pure self-consciousness achieved through a new moral consciousness that derives itself through absolute moral duty found in aiding other humans around the world which permitted moral obligation to extend beyond "internal division which [gives] rise to dissemblance." 52 In sum, a new ontology of existence needed to be achieved in human reasoning and consciousness to overcome the tendencies of exclusionary practices and politics in an increasingly global and international world, through the spirit of ethical conduct that finds duty to be the absolute essence, and that duty is tied to the well-being of others..$^{53}$ And yet, this universalism necessarily comes into tension with the simultaneous hope for multiculturalism and localism. Therefore, there was a reevaluation and re-contextualization of Hegelian dialectic of conflict for the twenty-first century that is supportive of global liberal goals and international concern innately tied to a universal moral Right, § 155

${ }^{50}$ Hegel, Phenomenology of Spirit, $\S 601$. See also, Hegel, Outlines of the Philosophy of

${ }^{51}$ Hegel, Outlines of the Philosophy of Right, § 157. If, as Hegel says, ethical action finds it fulfillment in a constitution (of a state), then the constitutions of universal human rights served as the de jure constitutions that would hopefully serve as the end to which substantial and universal order, along with public life, would be grounded on in modern liberalism.

${ }^{52}$ Hegel, Phenomenology of Spirit, $§ 634$.

${ }^{53}$ Ibid., § 601 .

(C) 2017 Paul Krause

https://www.kritike.org/journal/issue 21/krause december2017.pdf

ISSN 1908-7330

(cc) BY-NC-ND 
conviction, ${ }^{54}$ and was this not the end to which Fukuyama theorized? In this manner, modern global liberalism appropriated the form of Hegel's philosophy of history while rejecting its content.

By the embrace of this new dialectic in promotion of liberal internationalism (which is principally a dialectic of a struggle for), persons would no longer be dichotomized in the classical Marxist distinction of the proletarian against the capitalist, or the "constitutional pluralism" that Eric Nelson noted that was so profound in the formation of modern Europe..$^{55}$ Rather, people would see one another as being part of a universal human family (which would transcend race, gender, religion, and social class), united in the common struggle to actualize the ideals of freedom, liberty, equality, and inherent dignity that each person holds in the world. This understanding of oneself in the world would provide the authentic experience of moral living and endeavor in which the emptiness of doubt is replaced by reason leading to moral action. Such transformation on a personal and global stage was revolutionary. The erosion of nationalistic and exclusionary tendencies was the greatest hurdle for liberalism in the twentieth century to overcome. For only in that overcoming could a sustained commitment to internationalism be achieved. But what underpinned this struggle for internationalism was precisely the conflictual dialectic between liberalism and communism after 1945.

As a result, the hope of liberalism was that humans would recognize our relationship and responsibility to the global society but without the class distinction of the proletariat against the capitalists at the forefront, rather, the human drive for liberation against the institutions and classes inhibiting such liberation would be made paramount and would be the struggle for the common person as well as those committed to effecting change on an international level. ${ }^{56}$ It makes sense that liberalism would reject the Marxist analysis and move to a liberal Hegelian reading in its understanding of itself. Furthermore, the struggle for human freedom is a historical battle that concerns all persons regardless of nationality, religion, or political persuasion. Thus, the dialectic of modern liberalism and cosmopolitan democracy would necessarily inform society of the realization that democracy was the necessary course that History was taking - the triumph

${ }^{54}$ It is not my opinion that the re-contextualization of Hegel to fit a more progressive, liberal, model of historical progress was what Hegel intended. That said, various liberal theorists have used the Hegelian model to posit the end of history as the triumph of modern liberaldemocratic-capitalism.

${ }^{55}$ Nelson, The Hebrew Republic, 3-4.

${ }^{56}$ Lukács, 19-22.

(c) 2017 Paul Krause

https://www.kritike.org/journal/issue 21/krause december2017.pdf

ISSN 1908-7330

(cc) BY-NC-ND 
of liberal-democratic-capitalism at a universal scale to which all persons were innately yearning for..$^{57}$

The crisis with this embrace of an idea, however, is that it lacks the "bond of duty" by which the actualization of substantive liberty manifests itself. ${ }^{58}$ And without the rootedness of ethical order, ${ }^{59}$ the abstraction of only an idea to guide human ethical action in the world is in tension with Hegel's bond of duty being rooted in particularity ${ }^{60}$ Furthermore, in the aftermath of the shared experiences of the Second World War, it was easier for that generation, with its shared experiences, to move away from what was perceived as the problems that led to the catastrophe that swept across the world. What would then happen with the rise of the generation(s) without that experience and memory?

For these reasons, an entirely "new" conception of history was imagined in liberalism's understanding of itself in history, one in which conflict itself was being overcome by the march of progress in history and that history itself was destined to see the consummation of liberalism writ large. But as John Gray points out, this entire notion of humanist universal progressivism is but a secularization of Salvation History offered in the Abrahamic religions. ${ }^{61}$ Others before Gray, like Karl Löwith and Robert Nisbet, have also reminisced on the idea of progress as a secularization of salvific doctrine in Christianity. ${ }^{62}$ The problem with this new historicism, if course, is this: what happens when its determinist vision of History doesn't come true and when peoples have placed their faith in such a metanarrative? Like Dialectical Materialism, the strong-determinist vision of the future opens itself to disappointment when not realized. As Leo Strauss noted, the uniqueness of modernity was not the abject abandonment of "faith" but the marriage of Jerusalem (faith) with Athens (reason) to create a new Weltanschauung embodied in the zeal of ideology that presented faith as a reasoned determinism. Yet, long ago, Giambattista Vico equally warned against this conflation of faith and reason as he claimed that history was the invention of humans, premised upon what humans have thought up in their

\footnotetext{
57 In this sense, the evolution of democracy is also compatible with Hegel's evolutionary concept of human history, moving from despotism, to aristocracy, to the final state of human freedom and the realization of the State in history. That it was necessary for History to unfold in this manner is confirmable, of course, only in retrospection - the Owl of Minerva taking flight just as the "shades of night" are appearing.

${ }^{58}$ Hegel, Outlines of the Philosophy of Right, § 149.

${ }^{59}$ Refer back to supra note 11 .

${ }^{60}$ Hegel, Outlines of the Philosophy of Right, § 154.

${ }^{61}$ John Gray, Straw Dogs (New York: Farrar, Straus and Giroux, 2007), 4.

${ }^{62}$ See Karl Löwith, Meaning in History (Chicago: University of Chicago Press, 1949) and Robert Nisbet, History of the Idea of Progress (New York: Basic Books, 1980).
}

(c) 2017 Paul Krause

https://www.kritike.org/journal/issue 21/krause december2017.pdf

ISSN 1908-7330

(c) BY-NC-ND 
mind which he called "the conceit of nations" and "conceit of scholars," 63 which perpetuated what David Hume later called "false philosophy." ${ }^{6}$

The aftermath of 1989 and the fall of the Soviet Bloc did not signal the end of history in terms of liberal-democratic capitalism having emerged as the universal victor in the realm of the political. Rather, it simply marked the end of the Soviet Union and the Soviet Bloc as the enemy of the antithesis of Schmitt's national democracy built on the friend-enemy distinction. The fall of the Soviet Union led to the enemy "being vanished from the world" and thereby left the liberal West with no dragons left to slay, no mutual enemy to rally against for the cause of internationalism. The result has been the return to the domestic Sache rather than the international Sache of liberal expansionism as originally hoped, and the re-opening of internal conflicts that were only transiently overcome due to the phenomena of the Second World War and Cold War. ${ }^{65}$ This, in a way, opens anew the possibility of a return to the politics of self-correction which is inherent to national democracy but absent on the international level; a return to the bonds of duty and particularity Hegel discusses as the grounding for ethical action in life. ${ }^{66}$ Moreover, the historicist consciousness of progressivism which finds itself believing itself to be the universal dictum for the whole world runs the risk of becoming "violent and despotic ... in the name of [its] solution because it desire[s] to remove all obstacles to it." 67 Isaiah Berlin also noted that the pluralism of Romanticism and traditional conservatism were indispensable in taming the monistic tendencies of the idea of progress. Progress's drive to remove all obstacles to it consummation in the world returns to what Schmitt observed as a defining antithesis to democratic universalism: religion, culture, economics, and pluralism itself. ${ }^{68}$ Liberal democracies have now returned to their internal cores having flirted with universal and international ambitions only because of the circumstances of history in the twentieth century.

\section{Conclusion}

This is the great limit facing liberalism in the twenty-first century: the very dynamics which allowed it to flourish - the conflictual dialectic found

\footnotetext{
${ }^{63}$ Giambattista Vico, The New Science, trans. by Dave Marsh (New York: Penguin Books, 1999), 1.2.120-124.

${ }^{64}$ David Hume, A Treatise of Human Nature (Mineola: Dover Publications, 2003), 127.

${ }^{65}$ In some sense this is the return to Derrida's "democracy to come" located within the nexus of particular nations rather than the consummation of a universal order.

${ }^{66} \mathrm{Hegel}$, Outlines of the Philosophy of Right, §149, 154. 146.

${ }^{67}$ Isaiah Berlin, The Roots of Romanticism (Princeton: Princeton University Press, 1999),

${ }^{68}$ Schmitt, The Concept of the Political, 23.
} 
in the Second World War, the Soviet Union during the Cold War, and the Hegelianized reading of history of overcoming adversaries - have vanished. The idea of progress, as Robert Nisbet said even before the fall of the Soviet Union, was long at bay ${ }^{69}$ As he mused in 1980, "While the twentieth century is far from barren of faith in progress, there is nevertheless good ground for supposing that when the identity of our century is eventually fixed by historians, not faith but abandonment of faith in the idea of progress will be one of the major attributes."70 Robin Niblett, frank about the role that faith in progress has played in the development of liberal internationalism, even wrote, "The liberal international order has always depended on the idea of progress. Since 1945, Western policymakers have believed that open markets, democracy, and individual human rights would gradually spread across the entire globe. Today, such hopes seem naïve."71

The limits of liberalism and the crisis of cosmopolitan democracy are nothing short of the untenable and unstable metaphysics and historicism that undergirded it and attempted to transcend the historical foundations and rootedness of so-called liberal cultures. Like Marxism, the progressive impetus of modern liberalism took on a determinist view of history and secularization of certain precepts found in Salvation History that ultimately sowed the seeds of its own demise. This is not to say that liberalism itself is in crisis of disintegration, but the belief that liberalism would usher in the end of history seems unlikely to be revived any time soon.

Yale Divinity School, Yale University, United States of America

\section{References}

Berlin, Isaiah, The Roots of Romanticism (Princeton: Princeton University Press, 1999).

Berman, Paul, Terror and Liberalism (New York: W.W. Norton \& Company, 2003).

Blanshard, Paul, American Freedom and Catholic Power (Boston: Beacon Press, 1949).

Brown, Wendy, Undoing the Demos (Cambridge: MIT Press, 2015).

Derrida, Jacques, Politics of Friendship, trans. by George Collins (New York: Verso Books, 2005).

Ferrara, Christopher, Liberty, The God that Failed (Tacoma: Angelico Press, 2012),

\footnotetext{
${ }^{69}$ Nisbet, History of the Idea of Progress, 317.

${ }^{70}$ Ibid.

${ }^{71}$ Robin Niblett, “Liberalism in Retreat,” Foreign Affairs 96:1 (Janurary/February 2017),

17.

(C) 2017 Paul Krause

https://www.kritike.org/journal/issue 21/krause december2017.pdf

ISSN 1908-7330
}

(c) BY-NC-ND 
Fukuyama, Francis, Political Order and Political Decay (New York: Farrar, Straus and Giroux, 2014).

“The End of History?" in The National Interest 16 (Summer 1989). The End of History and the Last Man (New York: Free Press, 1992).

Gray, John, Straw Dogs (New York: Farrar, Straus and Giroux, 2007)

Gómez-Alonso, Modesto, "Spinoza on Freedom, Individual Rights, and Public Power," in Praxis Filosófica Nueva serie 40 (enero-junio 2015, 23).

Hamburger, Philip, Separation of Church and State (Cambridge: Harvard University Press, 2002).

Hazony, Yoram, "Nationalism and the Future of Freedom," in Mosaic (6 September 2016), <https://mosaicmagazine.com/essay/2016/09 Lnationalism-and-the-future-of-western-freedom/>.

Hegel, G.W.F., Outlines of the Philosophy of Right, trans. by T.M. Knox (New York: Oxford University Press, 2008).

Phenomenology of Spirit, trans. by A.V. Miller (New York: Oxford University Pres, 1977).

Reason in History, trans. by Robert Hartman (Upper Saddle River: Library of Liberal Arts, 1997).

Heidegger, Being and Time, trans. by Joan Stambaugh (Albany: State University of New York Press, 2010).

Hume, David, A Treatise of Human Nature (Mineola: Dover Publications, 2003).

Legutko, Ryszard, The Demon in Democracy (New York: Encounter Books, 2016).

Lilla, Mark, The Once and Future Liberal (New York: HarperCollins, 2017).

Locke, John, Second Treatise of Government, ed. by C.B. Macpherson (Indianapolis: Hackett Publishing Company, 1980).

Löwith, Karl, Meaning in History (Chicago: University of Chicago Press, 1949) and Robert Nisbet, History of the Idea of Progress (New York: Basic Books, 1980)

Luce, Edward, Retreat of Western Liberalism (New York: Atlantic Monthly Press, 2017).

Lukács, Georg, History and Class Consciousness: Studies in Marxist Dialects, trans. by Rodney Livingstone (Cambridge: MIT Press, 1972).

Moots, Glenn A., "The Protestant Roots of American Civil Religion," in Humanitas 23:1-2 (2010)

Murray, Douglas, The Strange Death of Europe (New York: Bloomsbury Press, 2017).

Nelson, Eric, The Hebrew Republic (Cambridge: Harvard University Press, 2010). 
Niblett, Robin, “Liberalism in Retreat," Foreign Affairs 96:1 (Janurary/February 2017).

Rawls, John, The Law of Peoples (Cambridge: Harvard University Press, 2001).

Russell, Bertrand, A History of Western Philosophy (New York: Routledge, 2004).

Schmitt, Carl, The Concept of the Political, trans. by George Schwab (Chicago: University of Chicago Press, 2007).

The Crisis of Parliamentary Democracy, trans. by Ellen Kennedy (Cambridge: MIT Press, 1988).

de Tocqueville, Alexis, Democracy in America (New York: Bantam Dell, 2000), 543-545, 616-617.

Weber, Max, "Politics as a Vocation" in The Vocation Lectures, trans. by Rodney Livingstone (Indianapolis: Hackett Publishing, 2004).

Vico, Giambtattista, The New Science, trans. by Dave Marsh (New York: Penguin Books, 1999). 